\title{
Unknown Unknowns: Is Virtue Something We Can Empirically Observe?
}

Shannon Rodgers

Simon Fraser University

Abstract: Given the general interest on the part of governments and educators to teach students about citizenship and character, it is worthwhile to examine particular assumptions about virtue, including that virtue is a definable thing or an identifiable set of qualities; that it can be observed and therefore known; and that it can be taught. Further, given the psychological research in this area and its subsequent impact on educational programs and policies, it is important for educators to question and contrast such research with the philosophical foundations (also influential on educational programs and policies) on which virtue is based.

\section{Introduction}

There are known knowns; there are things we know we know. We also know there are known unknowns; that is to say we know there are some things we do not know. But there are also unknown unknowns - the ones we don't know we don't know.

-Donald Rumsfeld, Former Secretary of State, 2002

Despite his notable unpopularity as former U.S. President George W. Bush's

Secretary of State, Donald Rumsfeld's philosophical musings about knowledge (for which he received much mockery) are important, and relate to the recent American Educational Research Association's conference theme, non satis scire (to know is not enough). To know is not enough but educators might consider a deeper challenge: question what we think we know in the first place. Serious consideration of the many "unknown unknowns" in education is a worthwhile undertaking and in particular, the possible unknown unknown, virtue, warrants further analysis.

There is interest on the part of governments and educators to teach virtue education and character development, generally as a means to help students become good citizens. Concerned with the politics of virtue education and character development programs, for example, Howard, Berkowitz and Schaeffer (2004) emphasize the importance of such 
programs thus,

... [it] comes with the territory of teaching and schooling. It is not a question of whether to do character education but rather questions of how consciously and by what methods. The political sands will shift and create different contexts. In spite of these changes, character education will continue and character educators will continue to grapple with questions of how to be our best ethical selves and how best to help students to know, care about, and do the right thing (p. 210)

They argue further that by choosing the profession, educators accept responsibility "...to

prepare individuals to make ethical judgments and to act on them...to do what one thinks ought to be done" (p. 189) and that as educators "... engage in preparing...youth to answer and respond to these and difficult personal issues and societal issues, their character development takes on growing importance” (p. 189).

The importance of virtue projects and character education programs have been newly emphasized as necessary, now more than ever, given our increasingly inter-dependent and global world. The Ontario Ministry of Education (2008), for example, points out this importance in Finding Common Ground: Character Development in Ontario Schools, K-12, stressing that educators are responsible for “... preparing students to be citizens who have empathy and respect for others within our increasingly diverse communities" (p. 2). Educators are further responsible to help students “...understand deeply the importance of civic engagement and what it means to be productive citizens in an interdependent world (p. 2).

Given this interest in teaching students about citizenship, virtues and character, it is worthwhile to examine particular assumptions about virtue, including, that it is a definable thing or an identifiable set of qualities; that it can be observed and therefore known; and that it can be taught. Further, given some of the psychological research in this area and its subsequent impact on educational programs and policies, it is important for educators to 
question and contrast this research with some of the philosophical foundations on which virtue is based -- philosophical foundations that are also influential on educational programs and policies. Interestingly though, philosophical foundations and arguments may have less sway than evidence-based research (including scientific and psychological research) in educational policy. As Biesta (2007) notes,

[p]roponents of evidence-based education stress that it is about time that educational research starts to follow the pattern that has created "the kind of progressive, systematic improvement over time that has characterized successful parts of our economy and society throughout the twentieth century, in fields such as medicine, agriculture, transportation, and technology" (p. 3)

Biesta further suggests “... some proponents go as far as to say that any practice not based upon scientific knowledge is inferior and should ultimately be banned" (p. 3). That scientific knowledge and research in education is considered superior to other forms of research or knowledge cannot be overstated as Biesta concludes that proponents of evidence-based education stress that,

...education "is too important to allow it to be determined by unfounded opinion, whether of politicians, teachers, researchers or anyone else." They call for a culture "in which evidence is valued over opinion" and argue that any approach to decision-making that is not evidence-based is simply "pre-scientific" (p. 4).

Considering this context, my purpose here is to explore some understandings of the nature of virtue by 1) examining the assumption that it can be observed or known; 2) looking at some of the literature that suggests it is observable and identifiable; and 3) discussing the implications as they relate to education.

While we may think we can observe virtue, such an assumption may be grounded on particular psychological, scientific perspectives. Further, the assumption may be counterintuitive to our desire to help students value and understand virtue in the first place. We unwittingly perpetuate the assumption when we assert that we can know one is virtuous by simply identifying observable, external behaviours. On the contrary, perhaps the inaccessible, 
deep interior of another--what she values, her intentions and her private thoughts are just that-inaccessible, at least to others. The problematic assumption that virtue is observable and can be known may be summarized thus:

Observability is fundamental to knowing;

Virtue is observable;

Therefore virtue can be known.

Of significance is that the second premise (virtue is observable) is widely assumed to be the case, particularly in education. It does seem reasonable, however, that we make such an assumption, considering the general acceptance of the first premise - that observability is fundamental to knowing. So is observability, in fact, fundamental to knowing? The assumption that it is, appears justifiable, at least at first.

Consider a high school student, for example, who is asked to find out the temperature at which water boils. She will observe and reasonably conclude that because the thermometer reads 212 degrees at the same time as the water begins to boil, she can therefore know (based on her observations) that water boils at 212 degrees. We could say that she knows it because she observes it. The problem occurs when the assumption that you can know it because you've observed it, is extended beyond the science classroom, and erroneously applied to human behaviours, intentions and private, mental deliberations.

Now consider a different example where one cannot necessarily know something based on observation. A school principal refers a student to a counsellor believing she knows that the internal, emotional state of a disruptive, grade 8 student during an opening day, school-wide assembly, is one of anger and ill manners. The reason for this assessment is based on first-hand, empirical observation that the student shouted obscenities at others and resorted to physical violence. In this context, it seems reasonable for the principal to assert knowledge of the individual's internal state, as evidenced by the observable, rude behaviour. 
The problem is that the conclusion (that the student is ill-mannered) could be incorrect and in fact was incorrect, in this particular case. As was later learned from the counsellor and student's parents, the principal, the staff and student body were all unaware that the student suffered from Tourette's Syndrome. Not only was the student acting involuntarily, he was not being intentionally rude. Sufferers of Tourette's Syndrome may, in reality, feel no malice or anger toward others at all when outwardly exhibiting an often embarrassing, sociallyunacceptable tic. Of importance in this example is the problem of observing what another values or intends at any particular time. Further, unlike the science student example where she apparently knows it because she observes it, the Tourettes example shows how the principal and others observed it but clearly didn't know it. These distinctions are crucial as they highlight the need to examine assumptions made about observability, knowability and teachability.

\section{Can Virtue Be Observed?}

Any review of the literature on virtue is sure to allude to the works of Plato and Aristotle - both of whom may have argued that virtue is not necessarily observable or knowable by others. In particular, Socrates seems to question the very nature of virtue. Specifically he questions whether or not virtue can be defined; whether it is one thing or many; whether it is a type of knowledge; and if it can be taught. At the end of the dialogue in Meno, for example, these questions remain unanswered, as Socrates notes that we can neither know what virtue is nor what it resembles (Hamilton \& Cairns, 1961).

Aristotle's work similarly suggests virtue may not be observable in any empirical sense, and that outward actions and behaviours do not necessarily tell us anything about what someone is feeling and thinking. Actions and behaviours do not necessarily tell us anything about whether or not someone is virtuous. Assessing the observability problem in Aristotle's descriptions of virtue, Geoffrey Sadler (2010) asserts that, 
[i] $t$ is not enough that actions be in accordance with the virtues for them to be done... The acting person must be in a certain condition...they must be aware of what they are doing... While actions (at least many of them) are empirically observable, states of character are not observable with the same ease (p. 13).

Some of the research in the fields of psychology and education, however, suggest that states of character or virtuous behaviours are definable, observable and even teachable. A famous study in "deindividuation," still studied today in introductory psychology classes, was conducted by psychologist David Dodd (1985). Dodd's study supposedly reveals that when otherwise "good college students" are given the promise of anonymity and the promise they will not be held responsible for their actions, they tend to act in a more antisocial manner and a less prosocial manner than prisoners. Asked to anonymously respond in writing as to what they would do if they were not held responsible for their actions, students responded that they would steal, cheat and in some cases even kill. Dodd's findings, while not intended to do so, nonetheless support the idea that virtuous, or in this case, non-virtuous characteristics or actions can be identified and observed - in this case by a researcher posing hypotheticals. Of further interest in Dodd's research, is that there can be a clear discrepancy between what a person may privately think, intend or value (stealing, cheating, killing) and their outward, observable behaviour - as of course none of Dodd's well-mannered and wellbehaved college students in fact committed the acts of which they wrote. Similar studies in psychology were also conducted by psychologist Philip Zimbardo (1970), which support Dodd's idea that when we believe we have anonymity and are not being observed, we are more likely to act and comport ourselves in an unvirtuous manner.

More recently, psychologist David DeSteno (2006), in a study funded by the National Science Foundation, found that when people feel gratitude, they are more generous and act virtuously by giving money to others. The experiment included 85 subjects who had to 
undergo a trying task and half of the subjects were instructed to perform the task again due to a computer problem. At the precise moment of the so-called computer problem, one of the researchers would tell these subjects that the computer problem could be fixed (and did so), providing relief and gratitude to these subjects, since they did not have to complete the task a second time. Following this part of the experiment, both the experimental and control group played a game where participants had to chose a dollar amount to give to each other. DeSteno describes how the participants, who felt grateful from the computer glitch experience, gave more generously - acted more virtuously - by giving $25 \%$ more than the control group members did. The conclusion then is that virtue (or virtuous behaviour) can be observed and known - namely, that knowledge of another's virtue can be discovered through simply observing outward action or behaviour such as the act of giving generously to others.

Psychologists Chris Peterson and Martin Seligman (2004) also suggest that virtue is outwardly observable, as they identify virtues and character strengths (including wisdom, courage, justice, etc.). They argue that if a person values these virtues and practices them, a person will ultimately achieve success or excellence. Peterson, Seligman \& Park (2004) further suggest that,

Character strengths can be defined as positive traits reflected in thoughts, feelings, and behaviors. They exist in degrees and can be measured as individual differences. We speculate that these are grounded in biology through an evolutionary process that selected for these predispositions toward moral excellence as means of solving the important tasks necessary for survival of the species (p. 603).

The corporate world has generally adopted the position that virtue can be outwardly observed and identified, as Dyck and Kleysen’s (2001) study suggests. In their work, Aristotle's Virtues And Management Thought: An Empirical Exploration Of An Intergrative Pedagogy, these researchers observed management students to assess whether they could be taught to 
notice in others Artistotelian virtues. In their conclusions, Dyck and Kleysen suggest that their findings offer empirical evidence that virtues can in fact be identified and observed in management behaviour. As they note,

Our findings offer preliminary empirical support for the contention that Aristotle's virtues provide a useable framework for integrating moral concerns into a holistic view of management. Our results, that students are able to observe the virtues in actual managerial behavior, encourage their further use and development as a framework for education in management theory and business ethics (p. 570).

The assumption that virtue is identifiable and observable is also reflected in some of the educational literature. Catherine Fallona (2000) in her work, Manner In Teaching: A Study In Observing And Interpreting Teachers' Moral Virtues, suggests there are moral virtues that are observable in teachers. Focusing on assessing "manner," Fallona measures the Artistotelian virtues of bravery, friendliness, wit, mildness, magnificence, magnanimity, honor, generosity, temperance, truthfulness and justice. Conducting her research in a middle school in Arizona, Fallona argues that,

... from detailed cases, one is able to see how a particular teacher expresses moral virtue in her practice...Through interviews, a card sort, observations, and video recordings, I gained an understanding of manner in teaching as the expression of moral virtue... Once I was able to identify teacher behavior that was reflective of virtue, I made focused observations. The focus of the observations was on the teacher's expressions of moral virtue (p. 7-9).

Though Fallona later mentions the difficulty of observing some virtues, there is nonetheless an assumption that virtues can be observed. Distinguishing between "visible" virtues and "invisible" virtues, Fallona still contends that even the invisible virtues just require a high degree of interpretation. Of the visible virtues, Fallona writes, “...the moral virtues whose expression are most observable are friendliness, wit, bravery, honor, mildness, generosity, and magnificence” (p. 9) and that “...these virtues can be observed in a teacher's actions, and thus require the least amount of interpretation" (p. 9). Of the invisible virtues, Fallona notes that "other virtues are not so visible. Thus, seeing them...requires high degrees of 
interpretation...magnanimity, temperance, truthfulness, and justice fall into this category (p. 10). Fallona's conclusions, like those of the researchers in psychology, suggest that virtue is not only observable in others, but can be quantified and in some sense, empirically known.

\section{Can Virtue Be Taught?}

As noted earlier, Socrates, in Meno, questions whether virtue is something that can be defined or taught. His student, Plato, author of the "Ring of Gyges" story from Republic, however, ironically offers several teachable moments on virtue. Through the use of the story, students might be given the opportunity to question and explore, as Socrates did, the same assumptions made about virtue. If given a ring that makes you invisible, would you behave any differently than if you were visible? Would you steal? Would you harm others; Would you break the law? After all, you couldn't be caught - you're invisible, so why be virtuous? The story asks one to consider what one does when no one is watching and thus opens up important pedagogical opportunities. It is often a revelation to students, for example, that the privacy of their emails, Facebook comments and blog entries are actually illusory privacy. Perhaps this illusion of privacy and anonymity might explain the less than virtuous behaviour of some, but it does seem legitimate for students to innocently inquire: why be virtuous if no one can see me or if I am not rewarded for being virtuous? Plato's powerful story, though a dialogue about justice, nonetheless, has implications for understanding what it is to be a virtuous person. Further, given the impact of technology on education and the subsequent social networking generation, educators might see a benefit in using social networking dilemmas as a bridge or a lens through which to question the assumption that virtue in another is observable and knowable. Additionally, teaching works like Plato's "Ring of Gyges" story can encourage students to recognize their own perhaps misguided understanding of privacy with respect to social networking, and how this social 
reality may relate to virtue.

Some of the research, particularly in the area of psychology, suggests that virtue is something that can be identified, quantified, observed and known. As suggested at the beginning of this paper, however, given that research is often used to justify educational programs, initiatives and policies, it might be important for educators to examine some of the underlying assumptions that such research may contain. Further, as a related but more general point, educators might want to question why observability and measurability are so crucial to their pedagogies in the first place. As Heesoon Bai (2012) suggests, focusing on the observable and measurable is a testament to our dependence on the empirical, scientific paradigm, where

...matters of the immeasurable have been either dismissed out of hand as irrelevant or fuzzy and touchy-feely, or they have been objectified and operationalized, and turned into some kind of measurable and even predictable phenomena...the empiricist worldview neither includes nor attends to the unknowable, unnamable, unseen, immeasurable, uncertain, and unpredictable" (p. 5-6).

Perhaps virtue is better understood in this context - the unseen, the immeasurable, and the unknown.

\section{References}

Bai, Heesoon (2012) President's Faculty Lecture, Simon Fraser University, March 29.

Biesta, Gert (2007) “Why 'What Works' Won’t Work: Evidence Based Practice And The Democratic Deficit In Educational Research" in Educational Theory, Vol. 57, Number 1, pp 122.

DeSteno, David and Bartlett, M.Y. (2006) "Gratitude And Prosocial Behaviour: Helping When It Costs You” in Psychological Science, Vol. 17, pp 319-325.

Dodd, David K. (1985) "Robbers In The Classroom: A Deindividuation Exercise" Teaching Of Psychology Journal, Vol. 12, No. 2, pp 89-91. 
Dyck, Bruno and Kelysen, Rob (2001) “Aristotle's Virtues And Management Thought: An Empirical Exploration Of An Intergrative Pedagogy" in Business Ethics Quarterly, Vol. H, Issue 4, pp 561-574.

Fallona, Catherine (2000) "Manner In Teaching: A Study In Observing And Interpreting Teachers' Moral Virtues" in Teaching And Teacher Education Journal, Vol. 16, pp 681-695.

Howard, Robert E., Berkowitz, Marvin W. and Schaeffer, Esther F. (2004) "Politics Of Character Education" in Educational Policy, Vol. 18, No. 1, pp 188-215.

Ontario Ministry Of Education (2008) Finding Common Ground: Character Development in Ontario Schools, K-12 at http://www.edu.gov.on.ca

Park, N., Peterson, C. and Seligman, M. (2004) "Strengths Of Character And Well-Being" in Journal Of Social And Clinical Psychology, Vo. 23, No. 5, pp. 603-619.

Peterson, C. and Seligman, M. (2004) Character Strengths And Virtues: A Classification System. Oxford University Press.

Plato, Meno in Plato: The Collected Dialogues (1961) NJ: Princeton University Press. Eds. Edith Hamilton and Huntington Cairns, p. 372.

Plato, Republic in The Collected Dialogues (1961) NJ: Princeton University Press. Eds. Edith Hamilton and Huntington Cairns, Book II, 359b-360b.

Rumsfeld, Donald, Former United States Secretary Of State (2002) Press Conference, February $12^{\text {th }}$.

Sadler, Gregory B. (2010) "The Virtuous Person as Norm in Aristotle's Moral Theory" in Government and History Faculty Working Papers, Paper 11.

Walsh, Tasha. (2007) "Women, Strength And Happiness" in Focus On Women Magazine, November Issue.

Zimbardo, P.G. (1970) "The Human Choice: Individuation, Reason, And Order Versus Deindividuation, Impulse And Chaos" in Nebraska Symposium On Motivation (NE: University of Nebraska Press).

\section{About The Author}

Shannon Rodgers is a graduate student at Simon Fraser University in Burnaby, British Columbia, Canada. Starting as an English teacher, she later wrote, developed and implemented provincial curriculum for Philosophy and now teaches Philosophy to high school students at Earl Marriott Secondary School in Surrey, B.C.. As a graduate student, Shannon's research interests include Philosophy of Education; Philosophy of Science; Philosophy of Mind; Cognitive Psychology; Assessment and Evaluation; Ethics in Education and Teacher Education. She currently resides with her husband and two daughters in White Rock, British Columbia, Canada and can be reached at srodgers@sfu.ca. 